\title{
GROUNDWATER CONTAMINATION IN KARST AREAS OF SOUTHWESTERN CHINA AND RECOMMENDED COUNTERMEASURES
}

\author{
ONESNAŽENJE PODZEMNIH VODA V KRAŠKIH OBMOČJIH \\ JUGOZAHODNE KITAJSKE TER PREDLOGI ZA PREPREČEVANJE \\ NADALJNJEGA ONESNAŽEVANJA
}

\author{
Fang GUO ${ }^{1,2}$, Daoxian YUAN ${ }^{1,2} \&$ Zhengjiao QIN ${ }^{1,2}$
}

\begin{abstract}
UDC 556.3:504.5(510)

Fang Guo, Daoxian Yuan \& Zhengjiao Qin: Groundwater Contamination in Karst Areas of Southwestern China and Recommended Countermeasures

Approximately 33\% of China is karstic. The most extensive karst areas are in southwestern China and cover approximately $540,000 \mathrm{~km}^{2}$. Southwestern China hosts some of the most typical karst landforms in the world and has important highquality karst water resources. Due to the rapid development of China, karst waters are threatened by various types of contamination. Detail field and laboratory investigations in five provinces including several cities in southwestern China were conducted in 2008 and 2009. Eighty-three springs and underground rivers were surveyed and water samples collected from each for laboratory analyses for major ions. Four main types of karst aquifer contamination were identified based on contaminant sources: rural and agricultural pollution, pollution from urban development and industry, pollution from mining, and accidental groundwater pollution. Several representative instances for each type of contamination and their impacts on the environment are discussed in more detail. Contamination countermeasures of karst waters and a framework for overall management of karst water resources in southwestern China are provided.

Keywords: karst aquifer, underground river, groundwater contamination, countermeasure, southwestern China.
\end{abstract}

\begin{abstract}
Povzetek
UDK 556.3:504.5(510)

Fang Guo, Daoxian Yuan \& Zhengjiao Qin: Onesnaženje podzemnih voda v kraških območjih jugozahodne Kitajske ter predlogi za preprečevanje nadaljnjega onesnaževanja

Približno 33\% Kitajske je kraške. Najbolj obsežne kraške pokrajine se nahajajo $\mathrm{v}$ jugozahodni Kitajski in se raztezajo preko okoli $540.000 \mathrm{~km}^{2}$ ozemlja. V jugozahodni Kitajski se nahajajo nekatere najbolj tipične kraške pokrajine sveta in zelo pomembne zaloge kraške vode, ki je visoke kakovosti. Kakovost voda pa je zaradi hitrega razvoja države ogrožena z različnimi tipi onesnaženja. V letih 2008 in 2009 so bile izvedene podrobne terenske in laboratorijske raziskave $\mathrm{v}$ petih provincah, vključujoč mnoga mesta jugozahodne Kitajske. Predmet raziskave je bilo 83 izvirov in podzemnih rek. Vzorci voda so bili analizirani v laboratoriju, da bi določili vsebnost glavnih ionov. Glede na vire onesnaženja so bili razpoznani štirje osnovni tipi onesnaževanja vodonosnikov: podeželjsko in kmetijsko onesnaževanje, onesnaževanje iz urbanih centrov in industrije, onesnaženje iz rudarskih dejavnosti ter onesnaženje ob nesrečah. Za vsak tip onesnaževanja je bolj podrobno predstavljenih nekaj reprezentativnih primerov ter opisan njihov vpliv na okolje. Predlagani so varovalni ukrepi za preprečevanje onesnaževanja kraških voda ter ukrepi za celotno upravljanje $s$ kraškimi vodnimi viri v jugozahodni Kitajski.

Ključne besede: kraški vodonosnik, podzemna reka, onesnaženje podzemnih voda, varovalni ukrep, jugozahodna Kitajska.
\end{abstract}

\footnotetext{
${ }^{1}$ Laboratory of Karst Dynamics, Institute of Karst Geology, MLR, Guilin 541004, People’s Republic of China

${ }^{2}$ The International Research Center on Karst under the Auspices of UNESCO, Guilin 541004, People's Republic of China e-mail: gfkarst@126.com
}

Received/Prejeto: 29.10.2009 


\section{INTRODUCTION}

Karst regions are characterized by unique surface and subsurface features and complex interactions with the atmosphere, hydrosphere and biosphere. Karst-aquifer systems are more vulnerable to contamination in comparison with other types of aquifers. Due to rapid infiltration of precipitation and aquifer recharge, high flow velocities, and short water residence times, natural attenuation of contaminants introduced into karst aquifers is often minimal resulting in the contaminants extending over large distances (Ford \& Williams 1989; Drew \& Hötzl 1999; Zwahlen 2004). Potential and actual sources of pollution to groundwater in karst areas are a common concern throughout the world (Böhlke 2002; Kovačič \& Ravbar 2005).

Karst areas in the People's Republic of China (PRC) occupy 3.44 million $\mathrm{km}^{2}$, accounting for one third of
China's territory. In southwestern China karst occupies about $540,000 \mathrm{~km}^{2}$, mainly in Guizhou province, but including western Guangxi, eastern Yunnan, southeastern Chongqing, southern Sichuan, and western Hunan and Hubei provinces (Fig. 1). In these areas, the population is about 100 million people. Cultivated land occupies $19.27 \times 10^{4} \mathrm{~km}^{2}$ and accounts for $18.3 \%$ of the total area. The climate is warm and humid. The annual precipitation ranges between 1,000 and 2,000 $\mathrm{mm}$ and the average temperature ranges between 15 and $20^{\circ} \mathrm{C}$. Despite the high annual precipitation, unavailability of water resources, because of the presence of karst and low surface water runoff, is usually the main factor restricting economic and social development. As a result, 8 million people are without reliable drinking-water sources in the karst areas of southwestern China (Yuan 2003).

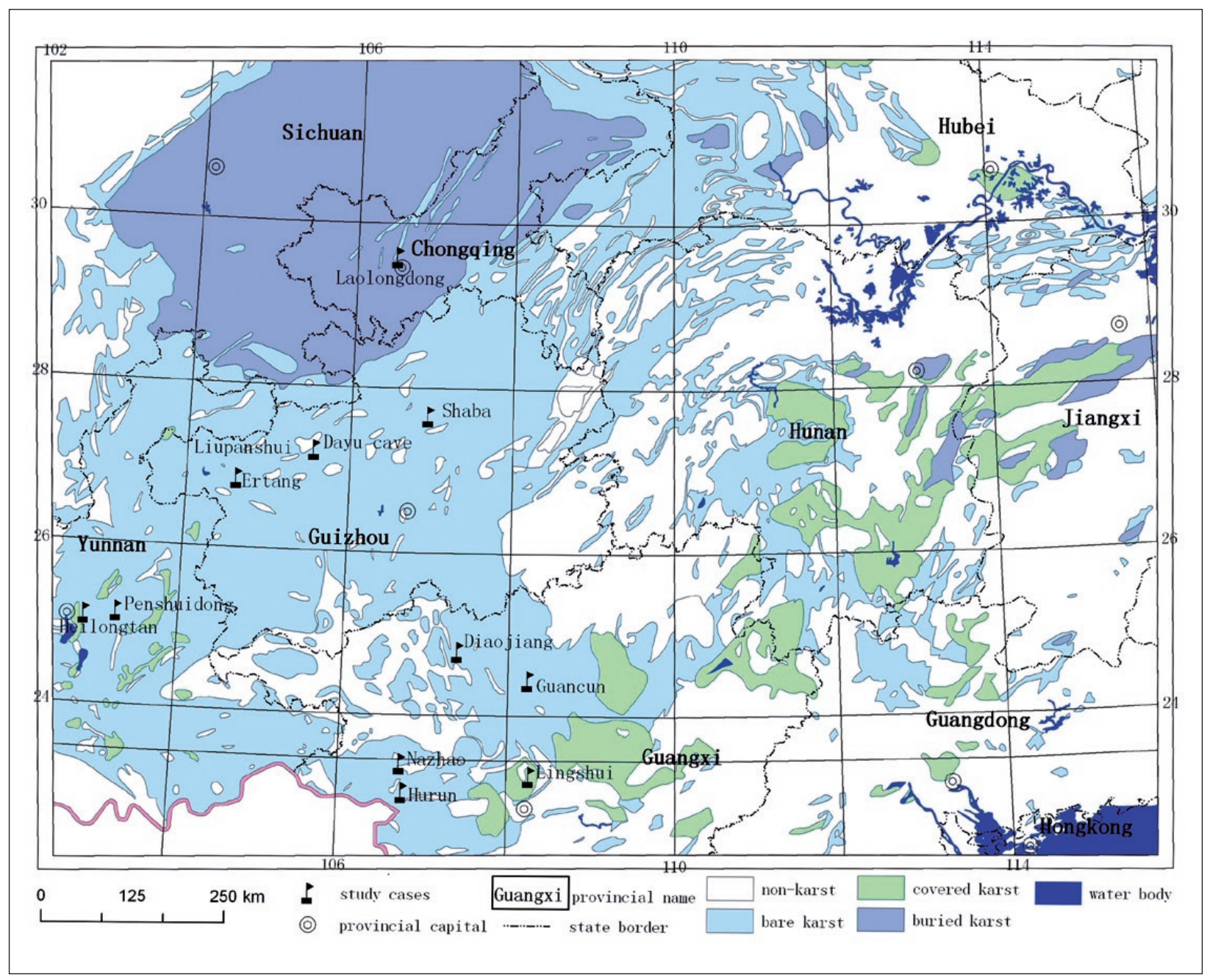

Fig. 1: Distribution of karst and study cases in southern China. 
Springs and underground rivers are the two main sources of water in southwestern China. In southwestern China there are 2,836 listed subterranean rivers with a total length of $13,919 \mathrm{~km}$ and a total discharge of $1,482 \mathrm{~m}^{3} / \mathrm{s}$. In Guizhou province there are 3,152 perennial karst springs with a minimum discharge greater than $10 \mathrm{~L} / \mathrm{s}$ during the dry season for a total of $257.82 \mathrm{~m}^{3} / \mathrm{s}$. Of the known subterranean rivers 1,130 are more than $2 \mathrm{~km}$ long and exhibit a total discharge of $212.78 \mathrm{~m}^{3} / \mathrm{s}$ during the dry season.

There are 604 underground rivers in Guangxi Autonomous Region with the total discharge of $191 \mathrm{~m}^{3} / \mathrm{s}$ in dry seasons. Within Guangxi, there are 201 karst springs that exhibit a minimum discharge greater than $50 \mathrm{~L} / \mathrm{s}$ during the dry season, for a total discharge of $37.09 \mathrm{~m}^{3} / \mathrm{s}$. Karst groundwater constitutes about $66 \%$ of the total water resources in Guangxi providing more than enough water for solving shortages if properly developed, managed and protected (Qian 2001).

Economic growth in southwestern China is rapid, bringing fundamental changes to traditional land use and human activities. Some of the activities that have the greatest impact on the environment include intensified agriculture, mining and infrastructure development (e.g., highway construction in Guangxi totaled $2,181 \mathrm{~km}$ in 2008 and is expected to exceed 5,000 km by 2030 ). Together with a growing industry and with urban expansion, these activities have caused varying degrees of contamination of karst aquifers throughout the region.

Groundwater-protection policies in China and consequently the protection of karst aquifers are part of the Law of the PRC. The Prevention and Control of Water Pollution law was proclaimed in May 1984 and revised in May 1996 and again in February 2008. Articles pursuant to the law Enterprises and institutions shall be forbidden to discharge or dump waste water containing toxic pollutants or pathogens or other wastes into seepage wells or pits, crevices or karst caves. The prohibitive provisions against sewage release to sinkholes can also be traced back to the "PRC Environmental Protection Law (Trial)" in section 20, which was adopted by the Standing Committee of National People's Congress in September 1979. Unfortunately, in the vast karst areas of southwestern China, these legal provisions are not strictly implemented. Water-resources protection also has specific provisions in the Technical Guideline for Delineating Source-Water Protection Areas, proclaimed in January 2007 by the Ministry of Environmental Protection of the PRC. Unfortunately, only some large springs in Northern China, such as Nianziguan Spring, have protection zones for water resources been established (Wu et al. 2010). As a result almost no karst-water resources have been legally protected in southwestern China.

This paper reviews actual and potential pollution of groundwater resources in selected karst springs or underground rivers in southwestern China. The paper does not represent a comprehensive study or precise classification and characterization of pollution in karst areas, but more a qualitative description of the most serious actual and potential pollutants. The purpose of this paper is to explain the distinction between the different types of anthropogenic impacts on groundwater quality in the selected karst aquifers and to depict the locations and types of hazards coming from different human activities. More karst aquifers in southwestern China need to be investigated in order to determine the extent of groundwater pollution and provide basic data for future groundwater management.

\section{METHODOLOGY}

In order to establish a fundamental database on the degree of karst groundwater pollution in southwestern China, field and laboratory investigations were conducted in 2008 and 2009 in Guangxi Autonomous Region, Guizhou, Yunnan and Guangdong provinces, and Chongqing Municipality. Investigations included surveying and sampling 83 springs, underground rivers, surface water, sinkholes and other karst features. The survey points were selected by the Provincial Geological Survey as representative of contaminated sites, planned drinking-water sources, and other locations of environmental interest. Measurements of $\mathrm{pH}, \mathrm{EC}$, and water temperature were made in the field using a pH/Cond 340i WTW Meter; $\mathrm{Ca}^{2+}$ and $\mathrm{HCO}_{3}^{-}$were measured in situ using portable $\mathrm{Ca}^{2+}$ and $\mathrm{HCO}_{3}^{-}$probes. Water samples were collected for determining the concentration of $\mathrm{K}^{+}, \mathrm{Na}^{+}, \mathrm{Ca}^{2+}, \mathrm{Mg}^{2+}$, $\mathrm{Cl}^{-}, \mathrm{SO}_{4}^{2-}, \mathrm{NO}_{3}^{-}, \mathrm{NO}_{2}^{-}$and $\mathrm{NH}_{4}^{+}$in the laboratory of the Institute of Karst Geology, PRC. Organic pollution was analyzed in the Laboratory of Organic Pollution, China University of Geosciences (Wuhan). Additional data presented in this paper were collected from the previous works. 


\section{RESULTS AND DISCUSSION}

\section{RURAL AND AGRICULTURAL CONTAMINATION}

Agriculture impacts on groundwater is related to landuse patterns and irrigation and crop and husbandry practices. The most important evidence of groundwater pollution from agriculture is the presence of nitrates and pesticides. Previous studies showed that some major ions in underground streams had increased greatly in the past two decades, especially nitrate and sulfate (Fig. 2) (Guo et al. 2002; Guo et al. 2008). Long-term monitoring for a typical karst-agricultural watershed in southwestern China shows $\mathrm{NO}_{3}^{-}$concentration in groundwater increased due to land application of fertilizers, sewage and livestock manure (Guo et al. 2007; Guo \& Jiang 2009). In many cases there is a clear connection between land use and water quality (Jiang et al. 2009; Jia et al. 2003). Pollution in rural areas is caused mainly by sewage and waste impacts. In rural areas of southwestern China, there are no landfills or centralized sewage-disposal systems. Sometimes karst depressions and sinkholes are used as landfills and include the direct unsupervised dumping of various wastes. Discharge water from the dumps usually has high organic pollution (Kogovšek 1996), nitrates and bacteria, which cause groundwater contaminated in karst-water systems.

Direct infiltration of raw or poorly treated domestic wastes is an important cause of groundwater pollution. Heilongtan spring in Kunming city is a famous karst

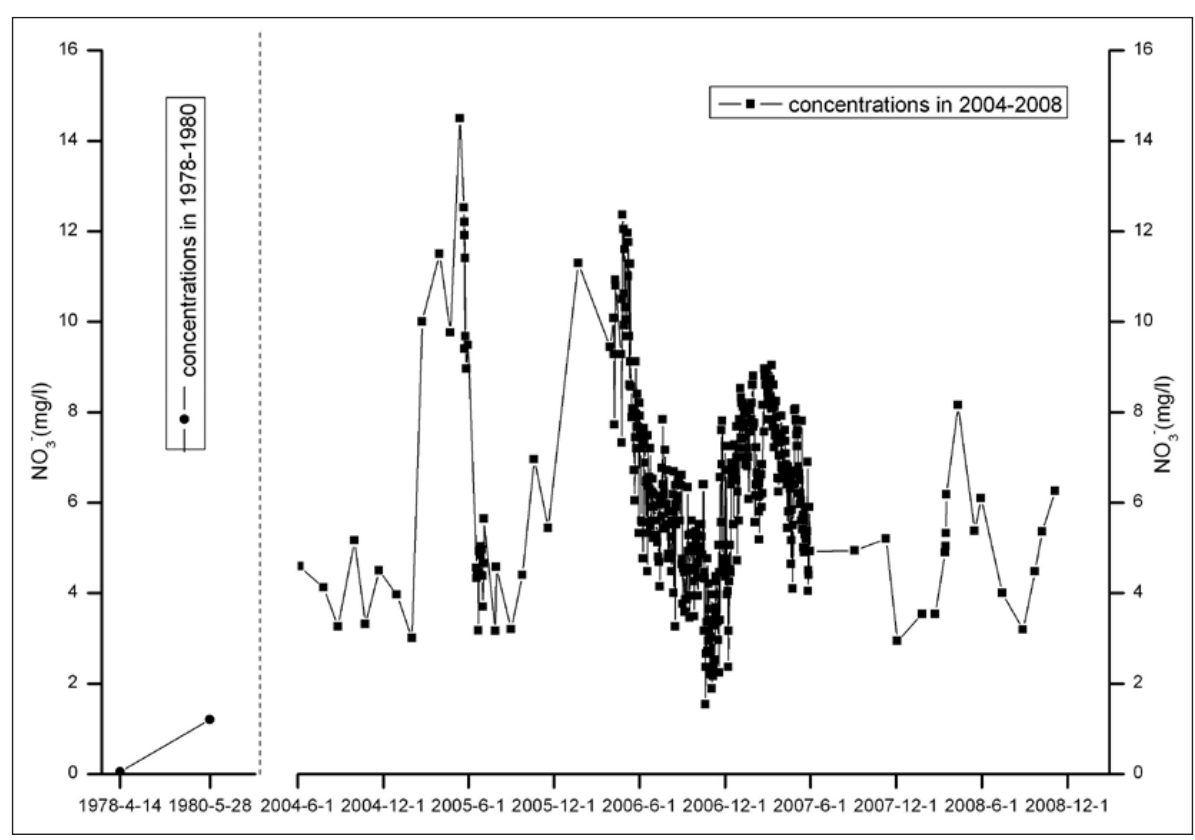

Fig. 2: Nitrate concentrations in Guancun underground river, Guangxi. spring in Yunnan Province (Fig. 3). Heilongtan spring water and groundwater in its vicinity were of good quality before the 1960s. The $\mathrm{pH}$ typically ranged from 7 to 8 , and contamination was rarely detected. Since the 1980s, Heilongtan spring quality has been steadily deteriorating; $\mathrm{Cl}^{-}, \mathrm{COD}, \mathrm{NH}_{4}-\mathrm{N}, \mathrm{NO}_{3}-\mathrm{N}, \mathrm{NO}_{2}-\mathrm{N}$ have all generally increased. Initially simple bicarbonate - calcium - magnesium water type now often dominates by sodium, chloride and nitrate ions. Contaminated water killed protected reddish fish on various occasions with most serious incidents occurring in October-December 2000 and February 2008.

There are two possible explanations for the origin of the Heilongtan-spring pollution. Dashao village, which is in the recharge area of the spring, has several landfill sites without seepage control. The waste leakage can enter karst aquifers directly via fractures or karst conduits. The other possibility is the inappropriate disposal of industrial wastes from a variety of activities in the area including machining, electronics, pharmaceutical, food processing, and plastics processing. Possible direct waste releases to sinkholes of toxic substances and sewage from these operations may be the cause of serious incidental contamination of karst groundwater and ultimately, Heilongtan spring.

Another example is Dayu Cave underground river. The inlet of Dayu Cave underground river is located in Longchang village, Dafang County, Guizhou Province. It is developed in middle Permian limestone. The inlet is a concentrated discharge for domestic wastewater of $\mathrm{Da}$ fang County. The wastewater is turbid, has a pungent smell, and discharges approximately $50 \mathrm{~L} / \mathrm{s}$. On July 18,2009 , wastewater samples exhibited a $\mathrm{pH}$ of 8.24 , an electrical conductivity of $673 \mu \mathrm{s} / \mathrm{cm}$, a water temperature of $25.3^{\circ} \mathrm{C}$, and a calcium concentration of $146 \mathrm{mg} / \mathrm{L}$. Concentrations of $\mathrm{Cl}^{-}, \mathrm{SO}_{4}^{2-}$ and $\mathrm{PO}_{4}^{3-}$ were exceptionally high (Tab. 1). The wastewater has been contaminating the underground river and cannot be used for drinking water or irrigation any longer. The maximum permissible concentration of total phos- 


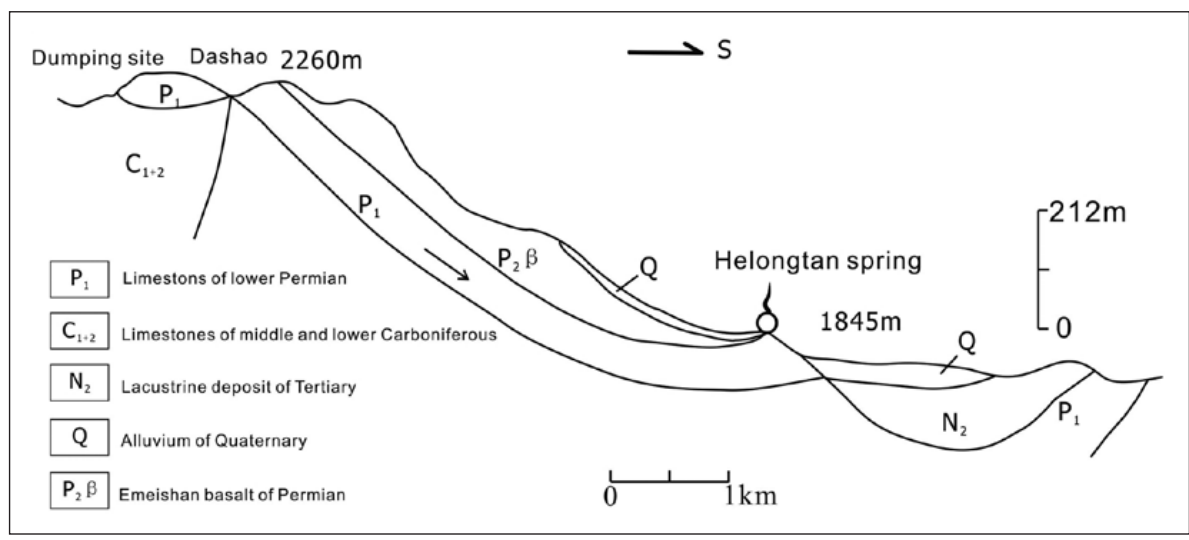

Fig. 3: Schematic hydrogeological profile of the Heilongtan spring, north of Kunming City, Yunnan Province.

phorus in drinking water from surface water ranges from $0.02-0.2 \mathrm{mg} / \mathrm{L}$.

Tab. 1: Water chemistry of inlet of Dayu Cave $(m g / L)$.

\begin{tabular}{llll}
\hline $\mathrm{Cl}^{-}$ & $\mathrm{NO}_{3}^{-}$ & $\mathrm{SO}_{4}^{2-}$ & $\mathrm{PO}_{4}^{3-}$ \\
\hline 39.5 & 8.8 & 26.3 & 11.2 \\
\hline
\end{tabular}

\section{CONTAMINATION FROM URBAN DEVELOPMENT AND INDUSTRY}

Industrial wastes are one of the most widespread sources of pollution in Liupanshui City, Guizhou Province, that is located in Shuicheng basin. Liupanshui City has been designated as a new industrial center for coal, steel, electric power and building materials production since the 1980s. All surface waters in Ertang town, which is part

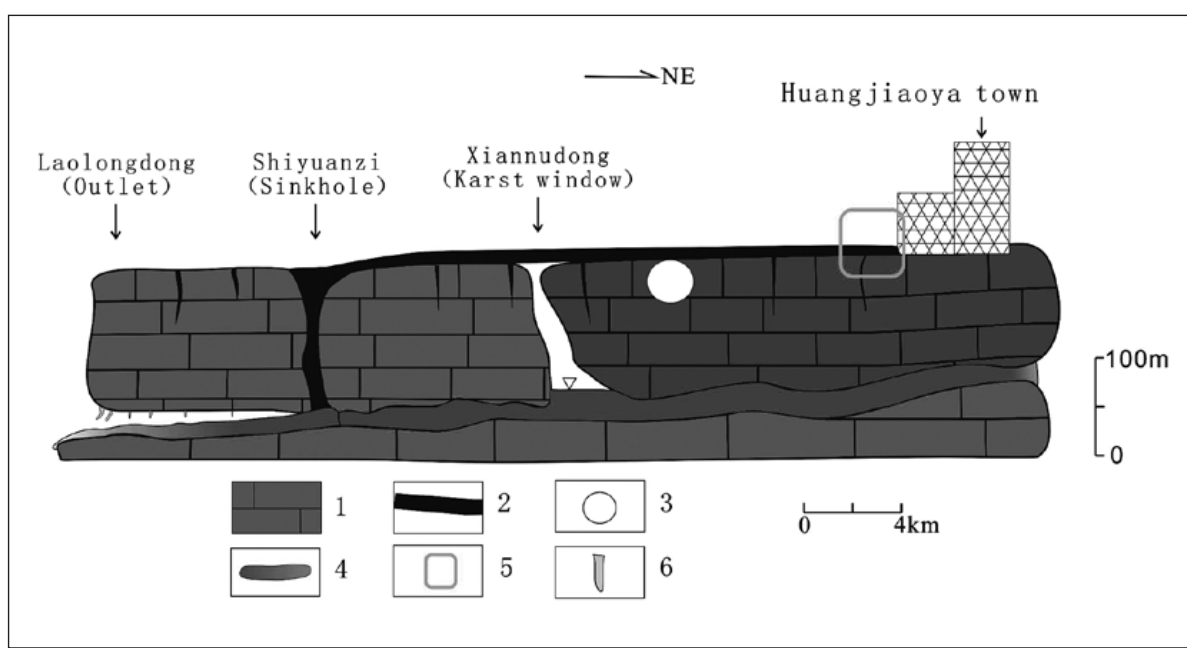

Fig. 4: Schematic cross-section of the Laolongdong underground river in Nanshan, Chongqing, (1) carbonate rock; (2) sewage channel; (3) highway tunnel; (4) underground stream; (5) drinking water protection area; (6) cave sediment. of the new industrial center, are now contaminated. Water samples collected on July 19, 2009 exhibited a $\mathrm{pH}$ of 7.98 , and electrical conductivity of $1700 \mu \mathrm{s} / \mathrm{cm}$, a water temperature of $21.2{ }^{\circ} \mathrm{C}$, and a calcium concentration of $286 \mathrm{mg} / \mathrm{L}$. The concentration of $\mathrm{SO}_{4}^{2-}$ was $1,111.64 \mathrm{mg} / \mathrm{L}$. Water samples of $\mathrm{Cr}^{6+}$ in a sinkhole in Shuicheng basin were $3,771 \mathrm{mg} / \mathrm{L}$ in 1990 . Contaminated surface-water streams sink into the karst underground causing serious pollution of underground karst waters.

Laolongdong underground river lies in Chongqing Municipality. It originates within the core of the Nanshan anticline. The aquifer is developed primarily in the lower Triassic limestones, dolomites, and dolomitic limestones intercalated with breccia limestones. Interlayering of carbonate rock and sandstone along the periphery of the anticline acts as a aquifuge, forming a typical trough-valley type underground river. The total area of the valley is about $20 \mathrm{~km}^{2}$. The upstream area of Laolongdong underground river is inhabited by more than 50,000 people living in Huangjiaoya town that includes a college and large scale cement plant. There are no sewage-treatment plants in the drainage basin. Only a small portion of wastewater from the town and plant discharge to a sewage channel at the surface; most wastewater is discharged directly into the surface water, thus seriously threaten-

ing groundwater quality. The outlet of Laolongdong underground river is a tourist spot where many people enjoy boating (Fig. 4).

Water samples were collected at different times at the outlet and karst window of the underground river. The results are shown in Tab. 2. The underground river is contaminated, especially with $\mathrm{Cl}^{-}, \mathrm{NO}_{3}^{-}, \mathrm{SO}_{4}^{2-}$, and $\mathrm{PO}_{4}^{3-}$, which is mainly due to domestic and industrial wastewater. Organic contaminants have been detected as well. Organochlorine pesticides (OCPs) in the water and soil at the outlet were 35 
Tab. 2: Chemistry of water in the caves of Laolongdong and Xiannudong.

\begin{tabular}{lllllll}
\hline Location & Date & $\begin{array}{l}\mathrm{EC} \\
(\mu \mathrm{s} / \mathrm{cm})\end{array}$ & $\begin{array}{l}\mathrm{Cl}^{-} \\
(\mathrm{mg} / \mathrm{L})\end{array}$ & $\begin{array}{l}\mathrm{NO}_{3}^{-} \\
(\mathrm{mg} / \mathrm{L})\end{array}$ & $\begin{array}{l}\mathrm{SO}_{4}^{2-} \\
(\mathrm{mg} / \mathrm{L})\end{array}$ & $\begin{array}{l}\mathrm{PO}_{4}^{3-} \\
(\mathrm{mg} / \mathrm{L})\end{array}$ \\
\hline Laolongdong & 29 April 2008 & 799 & 34.6 & 26.8 & 137.5 & 0.7 \\
& 20 June 2008 & 705 & 33.4 & 33.7 & 129.3 & 0.7 \\
& 11 July 2008 & 810 & 36.4 & 26.8 & 133.9 & 1.1 \\
& 20 October 2008 & 770 & 45.8 & 13.4 & 123.1 & 1.9 \\
& 12 March 2009 & 893 & 48.2 & 6.0 & 81.0 & 3.7 \\
\hline Xiannudong & 29 April 2008 & 901 & 45.3 & 25.3 & 130.6 & 1.7 \\
& 11 July 2008 & 876 & 45.9 & 18.8 & 88.0 & 2.4 \\
\hline
\end{tabular}

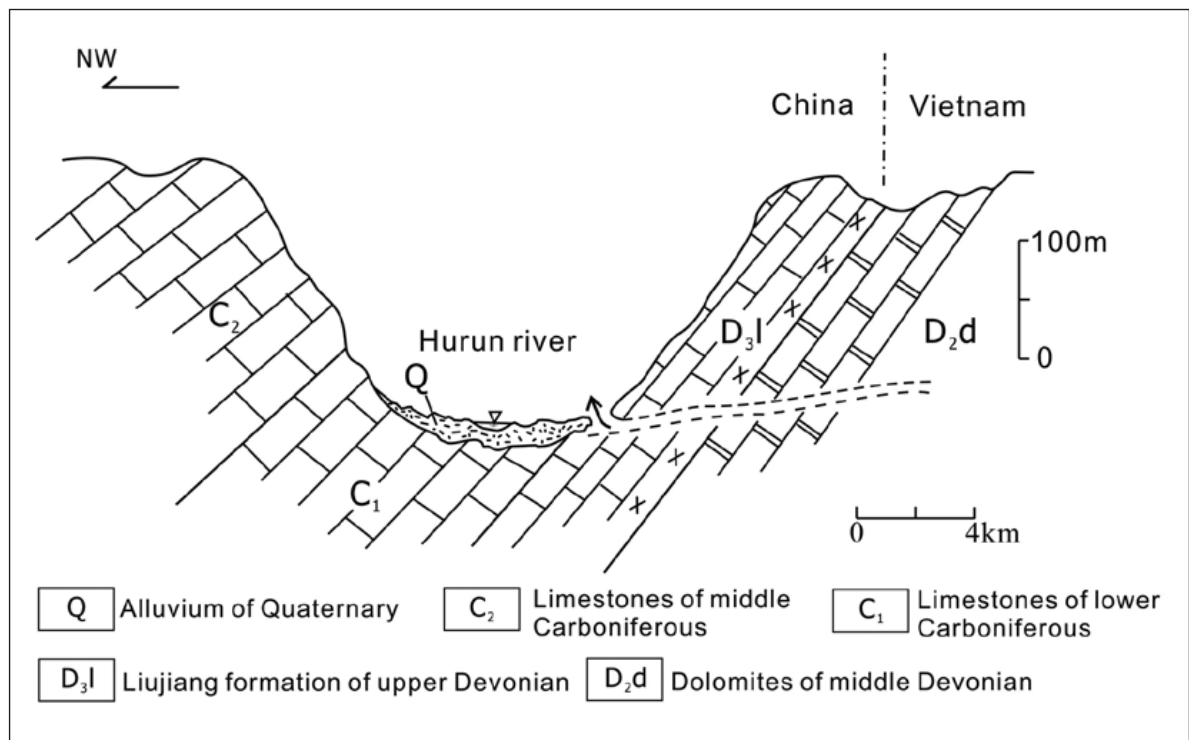

Fig. 5: Underground river polluted by manganese mining in Hurun, Guangxi.

\section{CONTAMINATION FROM MINING}

Mining has led to serious surface-water and groundwater contamination. The contaminants are mostly heavy metals such as gold, iron, copper, lead, zinc, etc. Pollution resulting from mining is the most serious problem in southwestern China and is attributable to both point and non-point sources. Southwestern China is rich in mineral resources that are distributed over large areas. For example, the Nanling metallogenic belt across Hunan, Guang-

$\mathrm{ng} / \mathrm{g}$ and $290 \mathrm{ng} / \mathrm{g}$, respectively in July 2008. The content of dichloro-diphenyl-trichloroethane (DDT) in the soil was $170 \mathrm{ng} / \mathrm{g}$.

Another example is contamination from sugar production. It is the major industry in Guangxi Autonomous Region. Wastewaters generally exhibit a low $\mathrm{pH}$ and high temperature. Impacts on groundwater quality are reflected in lowering DOC and sulfate bacteria. Water enriched with $\mathrm{CO}_{2}$ accelerates limestone dissolution and causes accelerated sinkhole development and land collapse (León \& Parise 2009). A good example of these degradation problems is the Nazhao underground river in Debao County, Guangxi. Wastewater from an alcohol plant located in the southwestern portion of Debao County is discharged directly into a nearby karst window causing biological and chemical degradation of groundwater. The outlet of Nazhao underground river, previously used for irrigation by the villagers, is now abandoned due to contamination. dong, Guangxi, and Jiangxi Provinces covers an area of about 16 million $\mathrm{km}^{2}$. The production of tungsten, tin, bismuth, lead, and zinc ranked first in the country. This area is also a major producer and processing base for non-ferrous metals. With increasing industrial development mining has gradually expanded. There are numerous small, scattered, and indiscriminate mining enterprises with poor management and a lack of mine restoration. Wastewater from mining operations is discharged directly into surface-drainage features which then recharge groundwater via karst windows, sinkholes or conduits. The contaminated groundwater migrates large distances via karst underground network and also impacts surface water in aquifer-discharge areas thus causing widespread contamination of water resources.

The Diaojiang River drainage area is located in the transition zone between Yunnan-Guizhou plateau and Guangxi Basin. It occupies $3,600 \mathrm{~km}^{2}$, of which, $3,000 \mathrm{~km}^{2}$ are in typical tower and depression karst of southwestern China and includes two cities and two 
Tab. 3: Dynamic variation of pollution and causes in Diaojiang River.

\begin{tabular}{llll}
\hline Year & Pollution index & Cause & Remark \\
\hline $1975-1982$ & $\mathrm{NO}_{2}^{-}, \mathrm{NH}_{4}^{+}-\mathrm{N}$ & Domestic sewage & \\
\hline 1994 & As and other heavy metal & mining & Treatment began in 1996 \\
\hline $2003-2004$ & $\mathrm{Fe}, \mathrm{Mn}, \mathrm{pH}, \mathrm{NO}_{3}^{-}, \mathrm{NO}_{2}^{-}, \mathrm{NH}_{4}^{+}-\mathrm{N}$ & Mining, domestic sewage & \\
\hline $2006-2007$ & $\mathrm{As}$ & Mining & \\
\hline $2008-2009$ & $\mathrm{SO}_{4}^{2-}, \mathrm{Zn}, \mathrm{Mn}$ and other heavy metal & Mining, domestic sewage & Re-treatment project started in 2006 \\
\hline
\end{tabular}

Tab. 4: Water quality variation of Xiakao, Diaojiang River

\begin{tabular}{|c|c|c|c|c|c|c|c|c|}
\hline date index & $p H$ & $\begin{array}{l}E C \\
(\mu \mathrm{s} / \mathrm{cm})\end{array}$ & $\begin{array}{l}\mathrm{Ca}^{2+} \\
(\mathrm{mg} / \mathrm{L})\end{array}$ & $\begin{array}{l}K^{+} \\
(\mathrm{mg} / \mathrm{L})\end{array}$ & $\begin{array}{l}\mathrm{Na}^{+} \\
(\mathrm{mg} / \mathrm{L})\end{array}$ & $\begin{array}{l}M g^{2+} \\
(m g / L)\end{array}$ & $\begin{array}{l}S r \\
(m g / L)\end{array}$ & $\begin{array}{l}\mathrm{Fe} \\
(\mathrm{mg} / \mathrm{L})\end{array}$ \\
\hline Aug. 2009 & 8.2 & 593 & 106 & 1.5 & 5.4 & 14.6 & 0.0 & 0.0 \\
\hline Sept. 2009 & 8.2 & 744 & 152 & 3.1 & 7.9 & 9.1 & 0.4 & 0.4 \\
\hline Oct. 2009 & 8.0 & 861 & 151 & 2.5 & 19.4 & 22.3 & 0.1 & 0.1 \\
\hline Nov. 2009 & 8.4 & 912 & 180 & 4.5 & 14.1 & 10.8 & 0.6 & 0.2 \\
\hline Dec. 2009 & 8.0 & 950 & 190 & 4.8 & 17.6 & 11.0 & 0.6 & 0.1 \\
\hline date index & $\begin{array}{l}M n \\
(m g / L)\end{array}$ & $\begin{array}{l}Z n \\
(m g / L)\end{array}$ & $\begin{array}{l}\text { As } \\
\text { (mg/L) }\end{array}$ & $\begin{array}{l}\mathrm{NO}_{3}^{-} \\
(\mathrm{mg} / \mathrm{L})\end{array}$ & $\begin{array}{l}\mathrm{PO}_{4}^{3-} \\
(\mathrm{mg} / \mathrm{L})\end{array}$ & $\begin{array}{l}F \\
(m g / L)\end{array}$ & $\begin{array}{l}\mathrm{Cl}^{-} \\
(\mathrm{mg} / \mathrm{L})\end{array}$ & \\
\hline Aug. 2009 & 0.0 & 0.0 & 0.0 & 15.0 & 0.0 & 33.2 & 0.0 & \\
\hline Sept. 2009 & 0.1 & 0.1 & 0.0 & 13.6 & 0.0 & 36.4 & 0.0 & \\
\hline Oct. 2009 & 0.1 & 0.0 & 0.0 & 11.7 & 0.8 & 34.1 & 0.0 & \\
\hline Nov. 2009 & 0.2 & 0.2 & 0.1 & 1.9 & 0.0 & 258.6 & 0.4 & \\
\hline Dec. 2009 & 0.4 & 0.7 & 0.0 & 5.6 & 0.2 & 310.2 & 0.5 & \\
\hline
\end{tabular}

counties. The outcrops in the drainage area are of Devonian, Carboniferous, Permian, Triassic, and Quaternary ages.

There are numerous industrial and mining enterprises located in the upstream and midstream areas of the Diaojiang River. Mining wastes are the major pollution source. Mining enterprises in the Diaojiang River catchment have been discharging wastewaters directly into Diaojiang and its tributaries for a long time, causing serious river-water pollution. Karst groundwater is also partially contaminated. The Diaojiang River authority has implemented a number of pollution controls although the controls have had some effect, the groundwater contamination is still not fully controlled (Tab. 3). In order to understand water quality changes in contaminated water bodies and explore the effects of remedial measures on Diaojiang River, a long-term monitoring program has been undertaken. Preliminary results indicate that water quality has improved, but the water is still significantly contaminated. Most of the ion concentrations are higher during the dry seasons than during the rainy seasons, especially $\mathrm{SO}_{4}^{2-}, \mathrm{Mn}, \mathrm{Zn}$ and other heavy metals (Tab. 4). One likely explanation is less dilution of the contaminant mass loading during dry seasons.

The manganese mine zone located in Hurun town to Xialei town, Guangxi is one of the largest manganese producers in China. Its reserves account for $70 \%$ of the total in Guangxi Province. The manganese mine is developed in lower Devonian rocks (Fig. 5). Mining activities have been expanding since 1967, and now include small privately owned mines. Underground rivers in the areas are well developed. For example, Hurun underground river, the drinking-water source for Hurun town, is contaminated by mining wastes. Measured $\mathrm{pH}$ and electrical conductivity of the outlet water were 7.14 and $961 \mu \mathrm{s} / \mathrm{cm}$, respectively. Concentrations of $\mathrm{Cl}^{-}, \mathrm{SO}_{4}^{2-}$ and $\mathrm{NO}_{3}^{-}$were also high, up to $10.5,319.6$, and $18.3 \mathrm{mg} / \mathrm{L}$, respectively. Heavy metals such as copper, lead, and zinc were also detected, including a high concentration of manganese at $14.7 \mathrm{mg} / \mathrm{L}$.

\section{ACCIDENTAL GROUNDWATER CONTAMINATION}

Karst areas are especially vulnerable to accidental groundwater contamination that can migrate large distances over short periods of time causing serious humanhealth risks and sometimes even deaths. Some examples include accidental leaks, accidental emissions from industrial plants, chemical explosions, and fuel spills from transportation vessels.

Assuming phosphorus sludge could be used as fertilizer, a villager dumped 120 tons of waste liquid into a karst depression in Penshuidong, Songming County, 


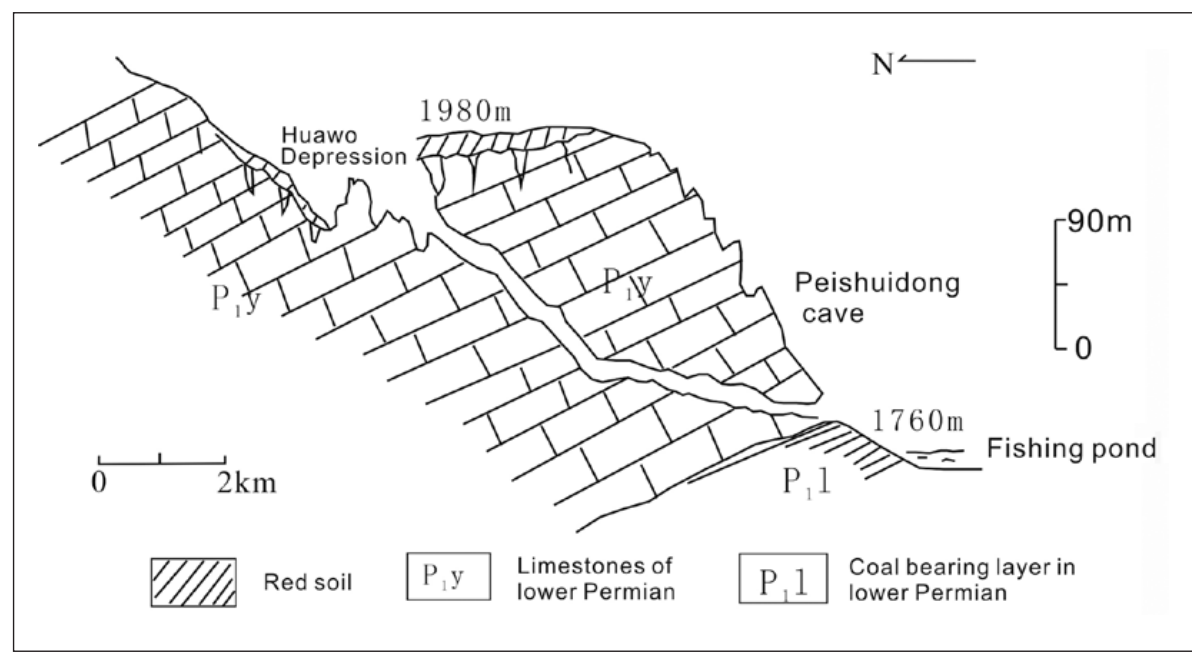

Fig. 6: Sketch hydrogeological profile of the cave of Peishuidong, Yunnan. of about 0.2 million dollar for emergency treatment. Ten thousand people depended on this water source and suffered from a shortage of safe drinking water. Sampling and monitoring at the groundwater outlet were implemented soon after the spill. The sampling results showed a breakthrough curve with a typical contaminant peak suggesting that the majority of the mass was quickly washed out of the karst system. However, elemental phosphorus concentrations since the acci-

Yunnan Province on February 24, 2008 (Fig. 6). About $20,000 \mathrm{~kg}$ of rainbow trout in a fish pond downstream from Penshuidong died, which caused a financial loss dent remained at a high and stable range (46-65 times higher than the limit set by the water quality standard for fisheries) (Shi et al. 2009).

\section{CONSEQUENCES DUE TO KARST GROUNDWATER POLLUTION}

The four primary consequences of karst groundwater contamination in southwestern China are:

(1) Abandonment of drinking-water sources. In the early 1980 's, $18 \%$ of the sewage in Zunyi City, Guizhou Province, discharged into a sinkhole connected to the Shaba underground river. The influent, which included wastewater from a cigarette factory, hotels, gas stations, hospitals and train stations, was poured into the underground river without any treatment. As a result, waterworks originating from the Shaba underground river had to be abandoned due to elevated concentrations of $\mathrm{Cl}^{-}$and $\mathrm{SO}_{4}^{2-}$ exceeding applicable drinking-water standards and because of the strong oil odor in groundwater.

(2) Restoration of contaminated karst aquifers is often difficult or not technically feasible; There is only one successful aquifer restoration case in China of karstgroundwater pollution caused by petrochemical enterprises in northern China. For cases of underground rivers in southwestern China, one of the main difficulties would be removal of sludge and contaminated sediments that act as long-term, secondary pollution sources that impact groundwater for decades to hundreds of years.
(3) Contamination of karst aquifers destroys underground ecosystems. Underground rivers in southwestern China present unique ecosystems, with great a diversity of species.

(4) Contamination of karst aquifers may harm or destroy the Ecological Defence toward the Yangtze River and the Pearl River. The Ecological Defence means a complex ecosystem located in a key part of certain area, which can well meet the ecological requirements of human beings living in its functioning area. Southwestern China is located upstream of these two rivers and is considered to be an Ecological Defence for the two rivers. Rock desertification and contamination of karst aquifers are two major threats fort this defence. Between February 1 and March 5, 2007, phosphorus concentration in the Chongqing-Youyang section of the Wujiang River, a tributary to the Yangtze River, ranged between 0.11 and $0.37 \mathrm{mg} / \mathrm{L}$, with a mean of $0.27 \mathrm{mg} / \mathrm{L}$, thus exceeding the national surface-water quality criteria for Class 3 streams. Contamination was attributed to the phosphorus chemical enterprises in Guizhou Province and the natural inter-basin transfer of water via a karst aquifer. 


\section{CONCLUSIONS, SUGGESTIONS AND COUNTERMEASURES}

Southwestern China is known for abundant resources of relatively high quality drinkable water, most of which have not been exploited. Karst groundwater is often considered as clean and plentiful natural resources despite the fact that it is extremely vulnerable to pollution. Karst water resources in southwestern China are threatened by a variety of anthropogenic activities. Four main types of pollution of karst aquifers have been identified based on the nature of the contamination sources and land use. Contamination from rural and agricultural sources leads to high concentrations of organic pollution, $\mathrm{Cl}^{-}$, and $\mathrm{NO}_{3}^{-}$in groundwater. Contamination from urban development and industry usually exhibit high electrical conductivity, $\mathrm{SO}_{4}^{2-}, \mathrm{PO}_{4}^{3-}$, heavy metals and other pollutants. Karst waters, polluted from mining activities, usually exhibit high heavy metal concentrations, such as manganese, lead, zinc, and iron. Accidental groundwater contamination can lead to serious harm to water supplies and great financial loss. Although karst groundwater resources in southwestern China are plentiful, few are protected. Because various forms of karst covers large areas in southwestern China more comprehensive studies on the distribution and degree of karst-water pollution in southwestern China should be conducted in order to establish a foundation for effective contamination countermeasures.

In 2007, seven Chinese academicians put forward suggestions for countermeasures on why and how to prevent karst underground rivers in southwestern China from becoming sewers. Their contribution was published as recommendations by the Chinese Academy of Sciences and was reported to the State Department. The Countermeasures listed below are based on these recommendations and are summarized from our studies.

(1) The pollution status of karst groundwater in southwestern China should be assessed with comprehensive investigations. Such new investigations need to be funded by the Ministry of Land and Resources, PRC and built upon previous studies initiated in 2000. This recommendation has been accepted and has resulted in a project entitled "Major Environmental Geological Problems and Countermeasures in Karst Mountain Areas in Southwestern China" and is currently underway.

(2) For important karst groundwater watersheds, the location of conduits system and flow directions of the water system should be identified using a variety of investigative techniques including dye-tracing tests. These analyses should include groundwater vulnerability evaluations. This recommendation has also been implemented and the initial results of the study were recently published (Zhang et al. 2007, 2009).
(3) Monitoring of karst underground rivers should be improved. Automated monitoring stations should be established based on the importance of karst conduits. Monitoring results should be widely publicized in order to promote the importance of resource protection by the whole society. An example of implementing this recommendation could be a public presentation by the Institute of Karst Geology from Guilin on some alarming trends observed at Lingshui Spring. Although the spring is utilized as the drinking-water source for Wuming County, Nanning, Guangxi, the hydrological and geological conditions of its drainage area are not well understood. Water quality is threatened by human activities while the discharge rate of the spring has been continuously decreasing over the last 30 years. As part of the overall spring assessment, an automated waterchemistry station at the outlet of the spring has been established in cooperation with Wuming Political Consultative Office and Wuming water companies. Isotope and dye-tracing tests and other methods were used to identify the source of water. In March, 2010, the county government invited researchers from the Institute of Karst Geology to give presentations on protection of Lingshui Spring in the regular political consultative conference.

(4) Strengthen scientific and technology studies by conducting field and laboratory experiments on the fate and transport of contaminants in karst aquifers and selfpurification capacity of underground rivers. Following this recommendation there has been an increased effort in studies of nitrate migration and transformation in karst aquifers of southwestern China.

(5) Enforcement of applicable regulations and enactment new regulations focusing on the unique hydrogeological characteristics of karst aquifers and their vulnerability. The people's governments at various levels should formulate specific rules and regulations to address the pollution problems. They should also, in accordance with the provisions of the Law of the Prevention and Control of Water Pollution of China, strengthen the prevention and control of water pollution.

(6) Public outreach and education on karst hydrogeology and protection of underground rivers should include training of rural teachers that are best positioned to engage the wider community of farmers. Local populations should be informed about ongoing field investigations and invited to observe dye-tracing tests designed to demonstrate the vulnerability of karst groundwater and the effects of contamination. Popular brochures and videos on the topics should be widely distributed. One example of implementing these recommendations is the 
publishing of a 2008 calendar that included locations of likely sources of contamination in the Guancun under- ground river drainage area. The calendars were distributed to each family in the area.

\section{ACKNOWLEDGEMENTS}

Financial support was provided by the China Geological Survey (1212010813111), Guangxi Natural Science Foundation (0991096) and Institute of karst Geology (200801, 2009001). We would like to thank the reviewers who read the first draft of this paper for their constructive comments. Special thanks to Neven Kresic and Malcolm Field for their great efforts in improving the language of the paper. Thanks are also due to Bureau of Geology of Guangdong Province, Guangdong Engineering Investigation Institute, Guangxi Bureau of Geology \& Mineral
Prospecting \& Exploitation, Guangxi Hydrogeological Team, Yunnan Bureau of Geology \& Mineral Prospecting \& Exploitation, Geological Survey of Yunnan Province, Bureau of Geology and Mineral Exploration and Development of Guizhou Province, Geological Survey of Hunan Province, China University of Geosciences (Wuhan), Southwestern University, Guangxi University for their field assistance and provided data. Thanks also to Junbing $\mathrm{Pu}$ for his valuable data.

\section{REFERENCES}

Böhlke, J.K., 2002: Groundwater recharge and agricultural contamination.- Hydrogeology Journal, 10, 153-179.

Drew, D. \& H. Hötzl, 1999: Karst hydrology and human activities.- A. A. Balkema, pp. 322, Rotterdam.

Ford, D.C. \& P.W. Williams, 1989: Karst geomorphology and hydrology.- Chapman and Hall, pp. 601, London.

Guo, F. \& G.. Jiang, 2009: Nitrogen budget of a typical subterranean river in peak cluster karst area.- Environmental Geology, 58, 1741-1748.

Guo, F., Jiang, G. \& D. Yuan, 2008: Change of major ions concentration in subterranean river in karst areas in South China.- Water Resources Protection, 24, 1, 16-19.

Guo, F., Jiang, G. \& D. Yuan, 2007: Major ions in typical subterranean rivers and their anthropogenic impacts in southwestern karst areas, China.- Environmental Geology, 53, 3, 533-541.

Guo, F., Jiang, G., Pei, J. \& C. Zhang, 2002: Assessment on the Water Qualities of major Subterranean Rivers in Guangxi and Their Changing Trend.- Carsologica Sinica, 21, 3, 195-201.

Jia, Y. \& D. Yuan, 2003: The impact of land use change on karst water in Shuicheng basin of Guizhou Province.- Acta Geographica Scinica, 58, 6, 831-838.
Jiang, Y., Wu, Y., Groves, C., Yuan, D. \& P. Kambesis, 2009: Natural and anthropogenic factors affecting the groundwater quality in the Nandong karst underground river system in Yunnan, China.- Journal of Contaminant Hydrology, 109, 49-61.

Kogovšek, J., 1996: How rubbish dumps have imperilled the quality of karst water, Kako smetišča ogrožajo kakovost kraške vode.- Annales, 9, 111-114.

Kovačič, G. \& N. Ravbar, 2005: A review of the potential and actual sources of pollution to groundwater in selected karst areas in Slovenia.- Natural Hazards and Earth Systems Science, 5, 225-233.

León, L.M. \& M. Parise, 2009: Managing environmental problems in Cuban karstic aquifers.- Environmental Geology, 58, 275-283.

Qian, X., 2001: Allowable withdrawal of groundwater in Guangxi karst region.- Carsologica Sinica, 20, 2, $111-116$

Shi, Z., Liu, X., Liu, Y., Huang, Y. \& H. Peng, 2009: Catastrophic groundwater pollution in a karst environment: a study of phosphorus sludge waste liquid pollution at the Penshuidong Cave in Yunnan, China.- Environmental Earth Sciences, DOI: 10.1007/ s12665-009-0071-z. 
Wu, Q., Xing, L., Zhou, W., 2010: Utilization and protection of large karst springs in China.- In: Kresic N. \& Z. Stevanovic (eds.) Groundwater hydrology of springs. Engineering, theory, management and sustainability. Butterworth-Heinemann, pp. 543-565, Burlington.

Yuan, D., 2003: Problems of geo-environment and ecohydrology in karst area.- Land resources in south China, 1, 22-25.

Zhang, C., Michèle, L., Jiang, Y. \& S. Wang, 2007: Duality method for assessing karst groundwater vulnerability and its application in Jinfo mountain of Chongqing.- Carsologica Sinica, 26, 4, 334-340.
Zhang, Q., Jiang, Y., Lin, Y., Liu, L. \& N. Hu, 2009: Karst groundwater vulnerability assessing based on Europe model.- Yangtze River, 40, 13, 51-54.

Zwahlen, F. (ed.), 2004: Vulnerability and Risk Mapping for the Protection of Carbonate (Karstic) Aquifers. Final report COST action 620.- European Commission, Directorate-General for Research, pp. 297, Brüssel, Luxemburg. 